\title{
THE THEORETICAL JUSTIFICATION OF INTENSIVE GENETIC POTENTIAL OF THE VARIETIES OF SOFT WHEAT
}

\section{V.V. NOVOKHATIN}

Research Institute of Agriculture for Northern Zayral'e, Federal Agency of Scientific Organizations, 2, ul. Burlaki, pos. Moskovskii, Tyumen Region, Tyumen Province, 625501 Russia, e-mail natalya_sharapov@bk.ru Received October 8, 2015

\section{Abstract}

Wheat, a hexaploid originated in Anterior (N.I. Vavilov, 1926) and the Central Asia (P.M. Zhukovsky, 1971), was widely spread and grown beyond the Fertile Crescent northerly and southerly. In this, cold resistant wheat and drought resistant spring forms have been originated in the course of unconscious selection (N.I. Vavilov, 1926; Qing-Ming Sun et al., 2009), and nowadays bread wheat is a dominant cereal crop cultivated worldwide (N.P. Goncharov, 2013). Analysis of origin of the soft wheat intensive breeds shows that more than 150 years, they were formed on the basis of the genetic material the secondary (P.A. Gepts, 2002; G.M. Paulsen, J.P. Shroyer, 2008), induced the peripheral centers with huge potential (R. Vencovsky, J. Crossa, 2003; S. Cox, 2009). Akagomughi, a short-strawed Japanese variety became the basis of intensive selection (N.I. Vavilov, 1987). A successful combination of genetic associations in derivatives of Hungarian (Banatka), Russian (Krymka), local Galician, English squarehead wheat and Chinese dwarfish wheat made it possible to create a high-yielding, adaptive intensive winter wheat variety Bezostaya 1. It was widely involved in the breeding for intensive yield production resulting in the best intensive high-yielding varieties of winter soft wheat. In the 1970s, these varieties were used to produce new spring wheat intensive varieties, such as winter-and-spring wheat Kazakhstanskaya 10 and spring variety Ikar. Note that the use of vernalized seeds of winter wheat for hybridization is not desirable because of temperature-induced mutations reducing the genetic value of the original forms. In crossing winter crops with spring crops it is necessary to allow them to pass flowering phase simultaneously (V.V. Novohatin et al., 2014). Discrete inheritance in each variety leads to certain changes in its biological, morphological, physiological and bio-climatic properties reflecting evolutionary direction in plant breeding. For example, Kazakhstanskaya 10 , created by hybridization of 39 varieties of which 23 one were winter wheat varieties possesses a well-developed, deep penetrating root system $(243 \mathrm{~cm})$, is tolerant to salinization, pre-harvest sprouting and fusariosis. Its potential yield under irrigation is $8.02 \mathrm{t} / \mathrm{ha}$. The variety is common in Central Asia and the south-east Kazakhstan, Bashkortostan, Kurgan and Tyumen regions. The variety Kazakhstanskaya 10 is involved in many breeding programs. As a result, a middle-ripening, medium-height, resistant to lodging and pre-harvest sprouting, intensive Ikar variety (winter wheat Bogarnaya $56 \times$ Kazakhstanskaya 10) (Pyrotrix) been created which genealogy includes 59 varieties of different ecological origin. Its distinctive features (the pubescence and darkcolored ears) contribute to the accelerated maturation of the grain, which is very important for Siberia and Trans-Ural Region. Data on full genealogy of created varieties allows us to control the hybridization of parental pairs when creating the desired genotypes and ecotypes.

Keywords: wheat, environment, genome, population, breeding, variety, area, primary and secondary centers, mutations, hybridization, transgressions, evolution

Spring bread wheat combines the genetic potential of the Triticum L. and Aegilops L. genera thanks to natural hybridization followed by amphidiploidization of genomes of monoploid Triticum urartu (einkorn) and two diploid species, the Aegilops speltoides and Ae. squarrosa. Einkorn T. urartu became the source of genome A, and Ae. speltoides of genome B. Their amphidiploid $T$. dicoccoides participated in the formation of a tetraploid $T$. dicoccum (Emmer, or hulled wheat), carrying the BBAA genome, and further attachment of the genome D from Ae. squarrosa allowed to produce a wheat hexaploid with the AABBDD genome [1-3].

According to N.I. Vavilov [4], the origin of bread wheat is associated 
with the Persian center of origin, while according to P.M. Zhukovsky [5] its birthplace was the Central Asian Center. This hexaploid became widespread in the territory of the Fertile Crescent, i.e. from Asia Minor to the Iran-Iraq frontier and from Palestine to the Turkish Caucasus, where its domestication completed up to the II millennium BC. Here started the original evolution of the species [3], which became the basis for its further changes [5, 6] that are ongoing till present $[7,8]$, which is confirmed by modern molecular methods [6].

The area of bread wheat expanded from the primary center of origin to the suburbs, where the recessive genes accumulated. To the north cold resistance was formed, while to the south - drought hardness [4] and springiness [9]. The long-term (hundreds of thousands of years) diffuse spread had led to the ecocentric principle and development of secondary [10, 11], and, later, of induced and peripheral $[12,13]$ centers of origin of species. Indeed, on the outskirts of the area, in the numerous valleys, mountain labyrinths of the Carpathians and the Pyrenees, with contrasting climate variations, increased ultraviolet insolation, extended days, and favorable water and mineral regime, there developed the secondary morphogenetic centers of origin. Thermal phytomutations and spontaneous hybrids developed, which accumulated biotypes with modified systems of $V r n$ and Ppd genes, contributing to their winter character. This expanded the possibilities of using agro-climatic factors and producing high yields [14]. The latter is largely driven by the genotype-environment interaction [15-17] which unequally manifest itself under different conditions [18]. Moreover, it is much more pronounced in new varieties $[19,20]$, and in the future it will be controlled and adjusted [21]. Wintering forms of bread wheat of the Carpathian origin (local Galician form, Banatka- and Taika-based varieties) emerged in the III-II millennium BC [22], and, due to the evolutionary variability, the crops accumulated extensive genotypes which were closely linked to environmental factors and ensured crop dissemination [23).

It is very important to engage valuable genetic sources from secondary and induced centers of origin [24-26]. In the secondary centers of origin, wheat for centuries was subjected to natural and artificial (unconscious and conscious, or systematic) selection. Species from other foci of morphogenesis penetrated here. The resulting populations were characterized by a high heterozygosity and a large number of subvarieties. Natural mutations and hybridization in the secondary foci contributed to the emergence of new transforms. These populations spread throughout Europe, and later penetrated into Russia. The proximity of Russia to the major centers of origin of the wheat had a beneficial effect on the formation of complex populations, consisting of various biological forms. For example, the Hungarian wintering variety Banatka became widespread in the southern regions of Russia and was the basis for drought-resistant Krymka varieties, tracing their origin from the X-VIII centuries BC [5, 22]. Through the Black Sea they penetrated into Turkey, and from there, acquiring the name Turkeus, into the Apennines, in Australia and North America, and also became the basis of all varieties in Central Europe.

The Banatka population gave rise to cultivated in the south-west of Ukraine (XVIII-XIX centuries) local winter populations. It had a high varietyforming ability, thereby becoming the basis of winter varieties produced by means of analytical selection, such as Ukrainka, Lesostepka 74, Lesostepka 75, Lutescens 17 (the female parent form of the Bezostaya 1 variety), as well as Zemka and Gostianum 237 (the parental forms of the drought-resistant high-quality variety Odesskaya 16) (see Fig.). Local varieties from Western Ukraine replenished the genetic resources of the crop in Germany, Italy, and the Czech Republic [24-26]. 


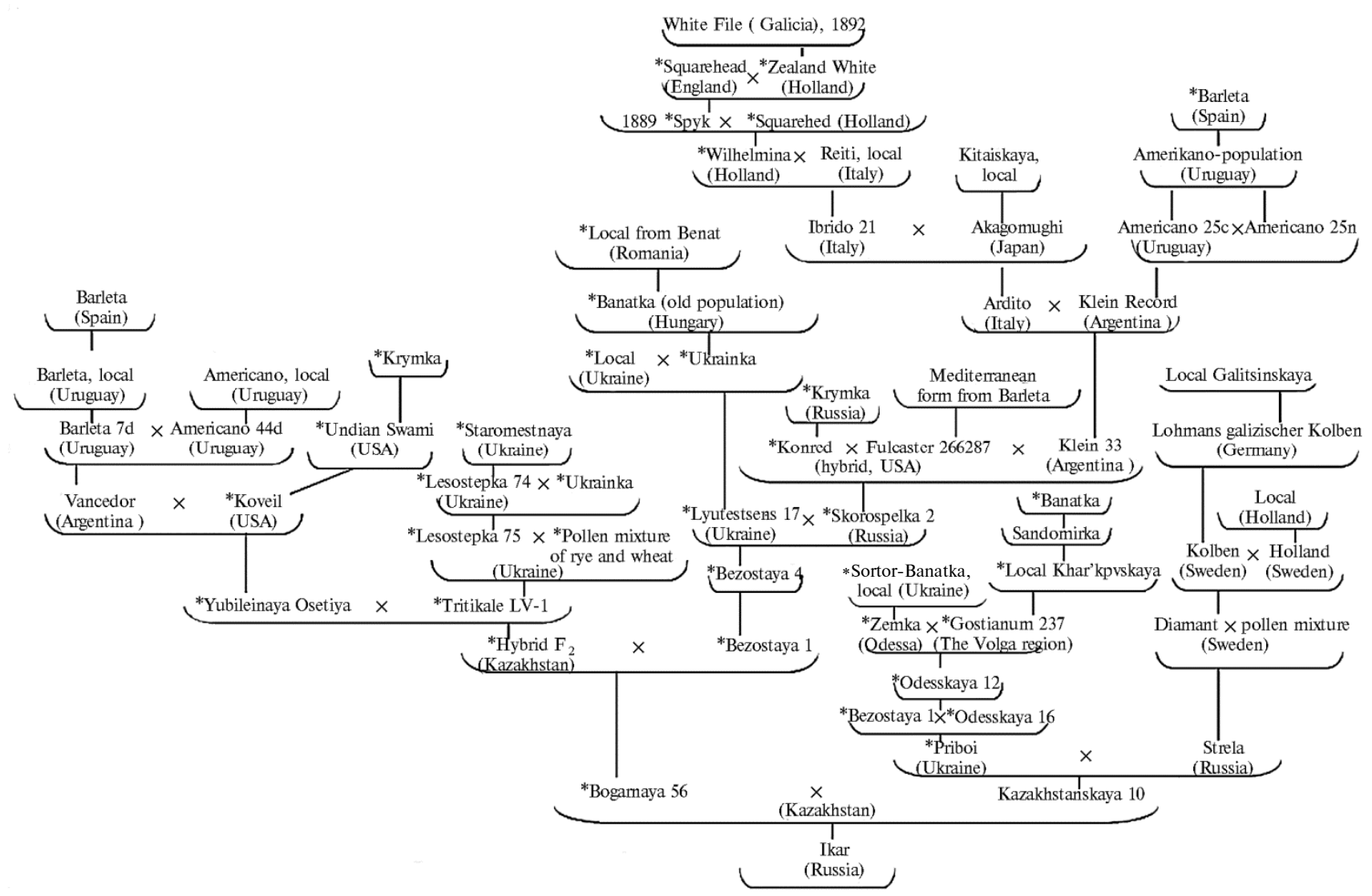

Pedigree and origin of intensive bread wheat (Triticum aestivum L.) varieties (winter forms marked with asterisks). 
At the beginning of the XVIII century, the Spanish population Barletta spread along with the settlers to South America. Under new conditions, during the transition from winter to spring forms, the impact of local factors on the populations led to the elimination of poorly-adapted biotypes. New phytomutations and spontaneous hybrids with an altered genetic structure appeared which greatly expanded the range of variability. Because of transgressions, in a setting of high pathogenic load, populations tolerant to rust and Fusarium fungi stood out against the remaining ones. When a directed formative process was applied, new associations between genetic systems were created within them, which led to the emergence of high-yielding forms, adapted to local conditions. The artificial selection of the best of them (the end of XIX-beginning of the XX century) gave rise to genetically diverse varieties which became the basis of the South American selection. The intensive Vancedor and Klein Record varieties, resistant to abiotic factors, spread through the region.

From the Krymka form, in the United States [11] the Koveil and the Konred varieties were selected, as well as a hybrid produced with the participation of the latter and the Mediterranean variety Fulcaster 266287 (see Fig.). Crossing the Argentinian variety Vancedor and the American variety Koveil allowed to produce the winter variety Yuzhnaya Ossetia (the Caucasian southern forest ecotype), which became the parent form of a strong, winter, droughtresistant cultivar Bogarnaya 56 of the dry steppe ecotype.

A local high-yielding plastic Galician population was widely used in the analytical selection and creation of breeding material in the UK, the Netherlands, Germany and Scandinavia. The participation of this population and the derivatives of high-yielding, resistant to lodging, low-quality English Squareheads allowed to release a well-known Dutch form Wilhelmina which was used as a female parent for producing the Italian variety Ibrido 21 . In the latter, a local form Rieti was the initial one $(\lesssim)$. Crossing Rieti with the Japanese cultivar Akagomughi [27], having the recessive genes of the short stature [28], gave a high-yielding form Ardito common in Italy which became the basis for intensive breeding [29]. In Argentina, with the participation of the Ardito variety () and a local variety Klein Record (a direct descendant of the Barleta), a short, highyielding, resistant to lodging variety Klein 33 was developed [27], bringing together a pool of genes from seven varieties of different geographical origin, such as the Netherlands, Argentina, Italy, Japan (their basis included Barleta, a local Galician wheat, English Squareheads and Chinese dwarfish wheat).

The American winter hybrid (ㅇ) Konred $\times$ Fulcaster 266287 and the Argentinian intensive variety Klein $33(\widetilde{\jmath})$ participated in the creation of the $\mathrm{Ku}$ ban' winter variety Skorospelka 2, which lacked winter hardiness and plasticity. These properties are characteristic of Lutescens 17, the variety of the same ecotype and a direct descendant of the variety Banatka in which the intensity was limited due to lodging. A combination of Lutescens $17 \times$ Skorospelka 2 was initial in creating the Bezostaya 4 variety, from which, by means of recurrent selection, the Bezostaya 1 of the southern forest-steppe ecotype was produced [30].

A successful combination of genetic associations in derivatives of Hungarian forms (Banatka), Russian forms (Krymka), local Galician, English Squareheads and Chinese short wheat made it possible to create a famous winter variety Bezostaya 1. This is mid-season, medium-grown, high-yielding, plastic, intensive variety, resistant to lodging, with high grain quality, having a high variety-forming ability. Bezostaya 1 is a male parent form of the heat and droughtresistant, winter-hardy variety Bogarnaya 56 (Pyrotrix subvariety) with high grain quality. Its female parent form was an interspecies hybrid produced by crossing the winter variety Yuzhnaya Ossetia (ㅇ) (a direct descendant of the Barleta and 
Krymka forms through Argentinian and American breeding) with a triticale LV-1 (created with the participation of the Ukrainian variety Lesostepka 75, a derivative of the Banatka variety and a mixture of wheat and rye pollen) [31]. The selection of intensive cultivars involves as a parent form the winter droughtresistant and tolerant to leaf rust Priboy variety, of the steppe ecotype, which was produced with the participation of the Bezostaya 1 (q) and Odesskaya 16 (a drought-resistant Banatka derivative) varieties. Its distinctive features include a well-developed, deep penetrating root system, resistance to Fusarium root rot [32] and a high grain quality [33].

The Priboy variety is involved in creating intensive varieties of spring bread wheat [34]. Success was a combination, in which the male parent was a spring, mid-season, high-yielding form Strela (Milturum subvariety), a spontaneous hybrid of Swedish variety Diamant, derived from the Swedish variety Kolben, local Galician wheat and the Swedish variety Holland (selected from a local Dutch form, produced with the participation of English Squareheads and a Galician population). In cool environment, the Strela variety is capable of forming a grain resistant to pre-harvest sprouting, and may actively ripen. The variety intensity is limited due to its tall stature and a tendency to lodging with its yield exceeding $3.0 \mathrm{t} / \mathrm{ha}$.

In a combination Priboy $\times$ Strela (the $F_{2}$ generation), the best plants were selected (Milturum subvariety) and reproduced for 3 years. From a segregating family, by means of recurrent selection, the 15612-13-77 line (Lutescens subvariety) was isolated which became the female parent of the spring midseason, medium stature, resistant to lodging, intensive variety Kazakhstanskaya 10 (winter-and-spring wheat). The variety possesses a well-developed, deeply penetrating root system (up to $243 \mathrm{~cm}$ ), is tolerant to fusariosis and pre-harvest grain sprouting, is common in Central Asia and the south-east Kazakhstan, where it is cultivated in saline rice rotations. Its maximum yield $(8.02 \mathrm{t} / \mathrm{ha})$ was obtained by the autumn sowing in the irrigated field of the Przhevalsky seed-trial ground in Kirghizia (now Kyrgyzstan), in 1987. As a spring variety, it became widespread in Bashkortostan, Kurgan and Tyumen regions. It is included in the list of valuable varieties. The genealogy of Kazakhstanskaya 10 involves 39 intensive varieties, including 23 winter ones, and covers all the secondary and most of the induced centers of origin of the culture. The variety boasts a well pronounced plasticity and combining ability, it is involved in many breeding programs. As a result, from a hybrid combination Bogarnaya 56 (winter) $\times$ Kazakhstanskaya 10 in the $F_{7}$ generation, the Pyrotrix 365 line was selected which became the Icarus variety (Pyrotrix subvariety). The obtained variety is mid-season, intensive, medium stature, resistant to lodging, hardy to pre-harvest sprouting, with a potential yield of 6.0-7.0 t/ha $[10,20]$. The presence of pubescence and dark-colored ear contribute to the accelerated passage of a milky ripeness-full ripeness phase, which is very important for the environmental conditions of Siberia and Transurals.

Hybridization with winter forms and varieties is considered of great importance for creating the intensive and highly productive breeding material of spring wheat. Meanwhile, the winter forms should be taken as the female parent ones, as they are able to transmit with a cytoplasm the genetic material that allows to form a well-developed secondary root system in the hybrids being created. It is undesirable to use vernalized seeds of winter varieties for the hybridization, as this gives rise to thermal phytomutations, which reduce the genetic value of the initial forms. When crossing winter and spring plants, it is required to combine such climatic conditions and technologies that allow both of the plants to simultaneously pass the flowering phase. This is feasible in southern Kazakh- 
stan (in the foothills of the Ala-Tau and in the Adler Microdistrict), as well as in the phytotron.

Intensive varieties of bread wheat have been formed for more than 150 years by selection based on the material from the secondary, induced and peripheral centers of origin, possessing a huge genetic potential for selection for adaptability. Such a selection is possible because of a discrete nature of inheritance manifestation, leading to changes in species diversity in terms of biomorphological and physiological and biochemical characteristics, and also has an evolutionary direction $[6,23]$. The complete parentage of the varieties being produced allows to theoretically justify the selection of parental pairs for crossing $[28,35]$, and to conduct a directed formative process and selection of genotypes of a desired ecotype. In addition, according to the law of homologous series by N.I. Vavilov (1987) and data on the crop genesis, one can plan the engagement of certain samples for the creation of the initial material to produce transgressions with a manifestation of characters, exceeding the parental forms. Cold and drought tolerance as integrated physiological parameters are controlled in spring wheat by many initial genetic systems. For example, in the setting of fierce dryfarming in the southeast Kazakhstan, cold-resistant intensive Scandinavian varieties have the same productivity as a drought-resistant variety Saratovskaya 29. This should be considered when creating new varieties with engagement of the genetic resources of drought resistance [36-38].

A large number of forms of different ecological and geographical origin are involved in the creation of modern varieties. Crossbreedings are effective, when varieties and forms, similar in biology and morphology, but genetically different, are used as parents. Regrouping the genes of the original forms that control quantitative and qualitative traits can result in the selection of genotypes with a discretely improved manifestation in the first case, and with a systematically accumulated manifestation in the second case. Intensive modern breeding is accompanied with microevolutionary processes [8], caused by recombinogenesis [39], the impact from environmental factors [40, 41], infectious load [42, 43] and the artificial selection [44, 45], which results in the formation within the populations a limited number of high-yielding, locally adapted biotypes with a pronounced synergism. Some of them become the parents of intensive varieties. This directed process leads to the impoverishment of species due to absence of demand and loss of many individuals and varieties. Therefore, it is required to develop a program for preserving the produced hybrid material (the $\mathrm{F}_{2}$ generation), derived in systematic breeding and genetic studies of varieties and forms with established genetic parameters, combining and variety-forming ability. In the future, this will allow for a more targeted and rapid production in the phytotron of the initial material and varieties with predetermined properties for any ecological niche. Creating the industrialbased varieties and their time-limited use will significantly reduce financial and human costs spent for the original seed growing.

Therefore, the parentage of the intensive varieties of spring bread wheat allows to justify the manifestation of biological and economically valuable traits and characteristics, and to choose parental forms for crossing, taking into account also the genetic potential of winter varieties. Crossbreedings are effective, when varieties and forms, similar in biology and morphology, but genetically different, are used as parents. Selection of genotypes with a discretely improved manifestation and a systematically accumulated manifestation of a trait are possible when regrouping the genes of the original forms that control quantitative and qualitative traits, respectively. 


\section{R E F E R E N C E S}

1. Migusheva E.F. Trudy po prikladnoi botanike, genetike i selektsii, 1975, 55(3): 3-26 (in Russ.).

2. L e 11 i Ya. Selektsiya pshenitsy [Wheat breeding]. Moscow, 1980 (in Russ.).

3. Go $\mathrm{n}$ c h a rov N.P. Vavilovskii zhurnal genetiki i selektsii, 2013, 17(4/2): 884-889 (in Russ.).

4. V a vilov N.I. Tsentry proiskhozhdeniya kul'turnykh rastenii [Centers of origin of crop plants]. Leningrad, 1926 (in Russ.).

5. Zhuk ovski i P.M. Kul'turnye rasteniya $i$ ikh sorodichi [Crop wild relatives]. Leningrad, 1971 (in Russ.).

6. Dvorak J., Luo M.-C., Akhunov E.D. N.I. Vavilov's theory of centres of diversity in the light of current understanding of wheat diversity, domestication and evolution. Czech $J$. Genet. Plant Breed., 2011, 47(Special issue): 20-27.

7. W i t c o m b e J.R. Methodologies for generating variability. Part 3. The development of base populations and their improvement by recurrent selection. Plant breeding and farmer participation. Rome, 2009: 139-157.

8. Srinivasan C.S., Thirtle C., Palla dino P. Winter wheat in England and Walles, 1923-1995: what do indices of genetic diversity reveal? Plant genetic resources: characterization and utilization, 2003, 1(1): 43-57 (doi: 10.1079/PGR20031).

9. Su n Q.M., Zhou R.H., G a o L.F., Z h a o G.Y., J i a J.Z. The characterization and geographical distribution of the genes responsible for vernalization requirement in Shinese bread wheat. J. Integr. Plant Biol., 2009, 51(4): 423-432 (doi: 10.1111/j.1744-7909.2009.00812.x).

10. G e p t s P. A comparison between crop domestication, classical plant breeding, and genetic engineering. Crop Sci., 2002, 42(6): 1780-1790 (doi: 10.2135/cropsci2002.1780).

11. P a u $1 \mathrm{~s}$ e n G.M., S h ro y e r J.P. The early history of wheat improvement in the Great Plains. Agronomy Journal, 2008, 100: 70-78.

12. Vencovsky R., Cross a J. Measurements of representativeness used in genetic resources conservation and plant breeding. Crop Sci., 2003, 43(6): 1912-1921 (doi: 10.2135/cropsci2003.1912).

13. S o k h S. Crop domestication and the first plant breeders. In: Plant breeding and farmer participation. S. Ceccarelli, E.P. Guimarres, E. Weltizien (eds.). Rome, 2009: 1-26.

14. Dochev V., Pe n chev E. Relationship between the structural elements and grain yield in winter wheat varieties, grown under various climatic conditions. Rasteniev"dni Nauki (Bolgariya), 2012, 49(5): 8-12.

15. N o v o k h a t i n V.V. V sbornike: Agrarnaya nauka i obrazovanie $v$ usloviyakh agrarnoi reformy $v$ Tyumenskoi oblasti: problemy, poiski, reshenie [In: Agricultural science and education in Tyumen region: challenges and approaches]. Tyumen', 1997 (in Russ.).

16. A n n i c c h i r i c o P. Coping with and exploiting genotype-by environment interactions. In: Plant breeding and farmer participation. S. Ceccarelli, E.P. Guimarres, E. Weltizien (eds.). Rome, 2009: 519-564.

17. Dopierala P., Kordas L. The effects of genotype-environment interaction on the yield and its structure in some winter cereals. Biuletyn Instytutu Hodowli i Aklimatyzaji Roslin (Warszawa), 2009, 253: 165-173.

18. Mohammadi R., Armion M., Sadeghzadeh D., Amri A., N a chit M. Analysis of genotype-by-environment interaction for agronomic traits of durum wheat in Iran. Plant Product. Sci., 2011, 14(1): 15-21 (doi: 10.1626/pps.14.15).

19. Novokhatin V.V., Shelomentseva T.V. Vestnik Rossiiskoi akademii sel'skokhozyaistvennykh nauk, 2014, 4: 14-17 (in Russ.).

20. Hildermann I., Messmer M., Kunz P., Pregitzer A., Boller T., Wi e mken A., $\mathrm{M}$ ä d e r P. Sorte $\times$ Umwelt - Interaktionen von Winterweizen im biologischen Landbau. Proc. 18 assemblée annuelle de la Société Suisse d'Agronomie (SSA) «Innovation im Pflanzenbau: von der Idee zur Umsetzung» (Zollikofen, 2010). Bulletin SGPW/SSA, 2010, 23: 163-165.

21. D ragavt sev V.A. V sbornike: Sovremennoe sostoyanie i priobretennye napravleniya razvitiya genetiki, epigenetiki, selektsii $i$ semenovodstva sel'skokhozyaistvennykh kul'tur [In: Current state and research areas of genetics, epigenetics, breeding research and seed production of crop plants]. Novosibirsk, 2013: 42-47 (in Russ.).

22. Zhuk ovski i P.M. Pshenitsa v SSSR [Wheats in the USSR]. Moscow, 1957 (in Russ.).

23. Levin S.A., Mulle r- Land au H.C., N a than R., C h a ve J. The ecology and evolution of seed dispersal: a theoretical perspective. Annual Review of Ecology, Evolution, and Systematics, 2003, 34: 575-604.

24. Knupffer H. The Balkan collections 1941-1942 of Hans Stubbe in the Gatersleben Gene Bank. Czech J. Genet. Plant Breed., 2010, 46(Special issue): 27-33.

25. Dotlačil L., Hermuth J., S t e hno Z., Dvořáček V., B radová J., Le išová L. How can wheat landraces contribute to present breeding? Czech J. Genet. Plant Breed., 2010, 46(Special issue): 70-74.

26. Torricelli R., Bernacchi M., Fa lci ne 11 i M. Missioni finalizzate alia collezione di risorse genetiche agrarie nel territorio dell'Ucraina occidentale. dal Seme, 2010, 5(1): 50-57. 
27. Vavilov N.I. Teoreticheskie osnovy selektsii [Theoretical bases for pant breeding]. Moscow, 1987 (in Russ.).

28. Ushiyama T., N a k a mura K., Anas, Yoshida T. Pedigree analysis of early maturing wheat cultivars in Japan for breeding cultivars with higher performance. Plant Prod. Sci., 2009, 12(1): 80-87 (doi: 10.1626/pps. 12.80).

29. Pshenitsy mira /Pod redaktsiei D.D. Brezhneva [World wheats. D.D. Brezhnev (ed.).]. Leningrad, 1976 (in Russ.).

30. Luk'y a n e n ko P.P. Selektsiya i semenovodstvo ozimoi pshenitsy [Winter wheat breeding and seed production]. Moscow, 1973 (in Russ.).

31. U r a z a 1 i e v R.A. Vestnik sel'skokhozyaistvennoi nauki Kazakhstana, 1997, 2: 22-29 (in Russ.).

32. $\mathrm{S}$ o z i n o v A.A., $\mathrm{K}$ i $\mathrm{r}$ i ch e $\mathrm{n} \mathrm{k} \mathrm{o} \mathrm{F.G.,} \mathrm{B} \mathrm{a} \mathrm{rd}$ a $\mathrm{n}$ o v M.I. Novyi sort ozimoi pshenitsy Priboi [Priboi, a new winter wheat variety]. Odessa, 1973 (in Russ.).

33. Dor ofe ev V.F., Yakubts i n e M.M., S e menova L.V. et al. Vysokokachestvennye pshenitsy [High-quality wheats]. Leningrad, 1972 (in Russ.).

34. Programma kompleksnogo selektsionno-semenovodcheskogo tsentra po rastenievodstvu GNU NIISKH Severnogo Zaural'ya na period 2011-2030 gg. /Pod redaktsiei V.V. Novokhatina. [A complex center for crop plant breeding and seed production in North Zauralie Research Institute (program for 2011-2030). V.V. Novokhatin (ed.)]. Tyumen', 2011: 22-51 (in Russ.).

35. Wit c o m b e J.R., V irk D.S. Methodologies for generating variability. Part 2. Selection of parents and crossing strategies. Plant breeding and farmer participation. S. Ceccarelli, E.P. Guimarres, E. Weltizien (eds.). Rome, 2009: 129-138.

36. Hede A.R., Skovmand V., Reynolds M.P., Crossa J., Vilhelmsen A.L., $\mathrm{St}$ ole n O. Evaluating genetic diversity for heat tolerance traits in Mexican wheat landraces. Genet. Resour. Crop Ev., 1999, 46(1): 37-45.

37. B örner A., La nd j e va S., S a l e m K.F.M., Lo hw a s s r U. Plant genetic resources a prerequisite for drought tolerance breeding in cereals. Proc. Jahrestagung der Vereinigung der Pflanzenzüchter und Saatgutkaufleute Österreichs (24-26 November 2009). Raumberg-Gumpenstein, 2010: 11-13.

38. D a vid M. Water loss from excised leaves in a collection of Triticum aestivum and Triticum durum cultivars. Romanian Agricultural Research, 2010, 27: 27-34.

39. Z hu che nk o A.A., K o rol' A.B. Rekombinatsiya $v$ evolyutsii $i$ selektsii [Recombination in evolution and breeding]. Moscow, 1985 (in Russ.).

40. Fuji mura S., Shi P., I wa ma K., Zhang X., Go pal J., J it s u y ma Y. Comparison of growth and grain yield of spring wheat in Lhasa, the Tibetan Plateau, with those in Sapporo, Japan. Plant Prod. Sci., 2009, 12(1): 116-123 (doi: 10.1626/pps.12.116).

41. M a lik A.H., Pri e to-Linde M.L., Kuktaite R., Andersson A., Johans s o $n$ E. Individual and interactive effects of genetic background and environmental conditions on amount and size distribution of polymeric proteins in wheat grain. Czech J. Genet. Plant Breed., 2011, 47(Special issue): 186-189.

42. Haberle J., Holzapfel J., Hartl L. Die Genetik der Fusariumresistenz in europaischem Winterweizen. In: Abwehrstrategien gegen biotische Schaderreger, Zuchtung von Hackfruchten und Sonderkulturen. Irdning, 2009: 5-8.

43. Ko s o v a K., Ch rpova J., S i p V. Cereal resistance to Fusarium head blight and possibilities of its improvement through breeding. Czech J. Genet. Plant Breed., 2009, 45(3): 87-105.

44. E 1 - H e nd aw y S.E., Ru a n Y., H u Y., S ch midhalt e r U. A comparison of screening criteria for salt tolerance in wheat under field and controlled environmental conditions. Journal of Agronomy \& Crop Science, 2009, 195(5): 356-367 (doi: 10.1111/j.1439-037X.2009.00372.x).

45. G u o R., W u Q., Li u Y. Single-plant similarity-difference selection in wheat breeding. $A d$ vance Journal of Food Science and Technology, 2013, 5(11): 1413-1417. 